\title{
SCIDOC
}

International Journal of Dentistry and Oral Science (IJDOS)

ISSN: 2377-8075

\section{Association Of Socioeconomic Status With Oral Hygiene Status And Periodontal Status Among Pa- tients Attending Private Dental College - A Retrospective Analysis}

Research Article

R. Keerthana ${ }^{1}$, Arthi Balasubramaniam ${ }^{2 *}$, Manjari Chaudhary ${ }^{3}$

${ }^{1}$ Saveetha Dental college and Hospitals, Saveetha Institute of medical and Technical Sciences, Saveetha University, Chennai, India.

${ }^{2}$ Senior Lecturer, Department of Public Health Dentistry, SaveethaDental College and hospitals, Saveetha Institute of Medical and Technical Sciences, Saveetha University, Chennai, India.

${ }^{3}$ Senior Lecturer, Department of Oral Medicine, Saveetha Dental College and hospitals, Saveetha Institute of Medical and Technical Sciences, Saveetha University, Chennai, India.

\section{Abstract}

\begin{abstract}
Socio-economic status has long held interest for its effect on general and oral health. Most evidence indicates that socio-economic inequalities are associated with oral health status. Periodontal health status is associated with age, smoking, systemic diseases, gender, genetics and utilisation of dental care. The study was aimed to find the association between socioeconomic status with oral hygiene and periodontal status. This retrospective study was conducted using records of patients visited private Dental College. A total of 98 consecutive case records of patient age ranging from 18-75 years were retrieved. Data on the oral hygiene status, periodontal status and socioeconomic status from their records were entered and subjected to statistical analysis. Descriptive statistics and Chi-square association was done to find the association of socioeconomic status with oral hygiene and periodontal status. One-way ANOVA was done to compare the mean oral hygiene and periodontal scores among different socio-economic status. Majority of the patients were from the upper middle class (31.6\%). Most of the patients had fair oral hygiene status (54.1\%) and also most of the patients had the beginning of the periodontal disease $(60.2 \%)$. There was no significant association of socioeconomic status with oral hygiene status and periodontal status $(\mathrm{p}=0.5$ and $\mathrm{p}=0.9)$. Mean oral hygiene score and periodontal score was high among lower middle class patients with no significant mean difference. Within the limits of the study, it was found that the upper middle class and upper class patients had better oral hygiene status and periodontal status due to multiple dental visits and appropriate use of oral hygiene measures and materials.
\end{abstract}

Keywords: Socioeconomic Status, Oral Hygiene Status, Periodontal Status, Association.

\section{Introduction}

The prevalence and distribution of the periodontal disease is worldwide. India is a country with more than one billion people living a diverse life in terms of geography, culture, tradition and even races. [1] There are also huge disparities present between socio-economic status of the people living in the country. [2-4] In India, periodontal disease is still the leading cause for the tooth loss in adults. It is a chronic inflammatory disease which leads to loss of attachment and deepening of the gingival sulcus that further causes loss of alveolar bone. [5, 6] Periodontal health status is associated with age, smoking, systemic diseases, gender, genetics and utilisation of dental care. [7] According to WHO, the preva- lence of periodontitis in the indian population is $70 \%-80 \%[8,9]$.

Socio-economic status has long held interest for its effect on general and oral health. Most evidence indicates that socio-economic inequalities are associated with oral health status [10, 11]. Monitoring social inequalities in oral health is important to provide information on population differences in oral health care needs, preventive practices and oral health system priorities $[12,13]$. Health is multifactorial, influenced by factors like genetics, environment, lifestyle, socio-economic status (SES) and many others. $[14,15]$ Economic status of the individual also determines the utilisation of the health services in a particular population $[16,17]$. Evidence has proven the existence of inadequate oral health in

\author{
*Corresponding Author: \\ Arthi Balasubramaniam, \\ Senior Lecturer, Department of Public Health Dentistry, SaveethaDental College and hospitals, Saveetha Institute of Medical and Technical Sciences, Saveetha University, Chennai, \\ India. \\ Tel: +919894977838 \\ E-mail: arthib.sdc@saveetha.com \\ Received: May 28, 2021 \\ Accepted: June 16, 202 \\ Published: June 25, 2021
}

Citation: R. Keerthana, Arthi Balasubramaniam, Manjari Chaudhary. Association Of Socioeconomic Status With Oral Hygiene Status And Periodontal Status Among Patients Attending Private Dental College - A Retrospective Analysis. Int J Dentistry Oral Sci. 2021;8(6):2900-2905. doi: http://dx.doi.org/10.19070/2377-8075-21000588

Copyright: Arthi Balasubramaniam 2021. This is an open-access article distributed under the terms of the Creative Commons Attribution License, which permits unrestricted use, distribution and reproduction in any medium, provided the original author and source are credited. 
lower SES groups as compared with higher SES groups $[18,19]$.

Previous studies have demonstrated that socioeconomic position is negatively associated with oral health and dental diseases [20, 21], which means the higher the socio-economic position, the better the perception of oral health and the less experience of dental diseases. $[14,22]$ It has been seen that poor health is related to lower economic status. [9, 17] In developing countries where illiteracy rates are quite high, education status plays a determining role in the health or a particular individual. [23, 20] Previously our team has a rich experience in working on various research projects across multiple disciplines [24-38].

Evidence has proven that association exists between oral health and socioeconomic status. The present study is carried out in order to find out the association between different socioeconomic groups with oral hygiene status and periodontal status.

\section{Materials And Methods}

\section{Study setting and design}

A retrospective study was conducted by reviewing 86,000 patient records of authors University hospital for a period of nine months from June 2019 to March 2020.

\section{Case records selection}

About 8564 consecutive case records of patients with age ranging from 18 - 81 years were sorted. 1289 case reports of patients with complete edentulism were excluded. Of 7275 patient records; 98 case records with recorded Oral hygiene index, Russel's periodontal index and socio-economic status were sorted and retrieved.

\section{Ethical approval}

Prior permission to utilize and to analyze the data from the case records of patients was obtained from the administration of University. (SDC/SIHEC/2020/DIASDATA/0619-0320)

\section{Data Collection}

The Oral hygiene index- simplified [39] and Russel's periodontal status [40] of these patients were retrieved. From the records personal information, socio economic status (SES) was obtained. Modified Kuppuswamy scale 2019 [41] was used for categorizing the individuals under different socio-economic groups based on their education, occupation and family income.

\section{Simplified oral hygiene index}

Oral hygiene status was assessed by Simplified Oral Hygiene Index (OHI-S) which was given by Green and Vermillion in 1960. It has two components, the Debris Index-Simplified (DI-S) and the Calculus Index-Simplified (CI-S), which are calculated separately and are summed up to get OHI-S for an individual. The examination was done using a mouth mirror and explorer. The interpretation of index is as follows: good-0 to 1.2, fair-1.3 to 3.0, and poor-3.1 to 6.0

\section{Russel's periodontal index}

Russel's periodontal index was given by Russel. A.L in 1956. It intended to estimate deeper periodontal diseases by measuring the presence or absence of gingival inflammation \& its severity, pocket formation, \& masticatory function. The scale of values range from $0-8$ with increasing prevalence \& severity of disease. 0.3-0.9 Simple gingivitis, 1-1.9 Beginning destructive periodontal disease, 2-4.9 Established destructive periodontal disease 5-8 Terminal disease

\section{Statistical analysis}

Statistical analysis was done using Statistical Package for the Social Sciences (SPSS) Version 23.0. Descriptive statistics was done to present the frequency distribution of socioeconomic status, oral hygiene index- simplified and Russel's periodontal index. Chi square association using crosstabs was done to find the association of socioeconomic status between oral hygiene index and Russel's periodontal index. One-way ANOVA test was done to compare means of oral hygiene index and Russels periodontal index scores. A p value $<0.05$ was considered to be significant.

\section{Results And Discussion}

In this study, 98 participants were included in which 45 were females and 53 were males. It was also noted that the majority were from the upper middle class $(31.6 \%)$, middle class $(31.6 \%)$ followed by lower middle class $(19.4 \%)$ and followed by upper class (17.3\%).(Figure 1)

The mean oral hygiene index score in the lower middle class was 2.3 (fair), middle class was 2.1(fair), upper middle class was 1.9 (fair) and upper class was 1.7 (fair). It was found that the mean oral hygiene score was high (fair) for the lower middle class. There was no statistical significant difference in the mean oral hygiene index scores among different socio-economic groups ( $p$ value $=0.490 ; \mathrm{p}>0.05)$ (Figure 2$)$

The mean of the periodontal index score in the lower middle class was 3.0 (established periodontal disease), middle class was 2.4 (established periodontal disease), upper middle class was 2.2 (established periodontal disease) and upper class was 1.8 (beginning of the periodontal disease). The mean of the periodontal index score was higher (established periodontal disease) in the lower middle class. There was no statistical significant difference in the mean periodontal index scores among different socio-economic ( $\mathrm{p}$ value $=0.292, \mathrm{p}>0.05)$ (Figure 3$)$.

Among the 98 individuals, majority were from the upper middle class $(31.6 \%)$, middle class $(31.6 \%)$ followed by lower middle class $(19.4 \%)$ and followed by upper class $(17.3 \%)$. In the lower middle class, 9 people had fair oral hygiene status, 5 people had good status and 5 had poor status. In the middle class, 14 had fair oral hygiene status, 12 had good status and 5 had poor status. In the upper class 12 had fair oral hygiene status, 4 had good status and 4 had poor. In the upper middle class 18 had good oral hygiene status, 9 had good and 4 had poor status. It was found that the upper middle class and middle class had better oral hygiene status $(31.6 \%)$ and the results were not statistically significant. There was no significant relationship between socioeconomic status and oral hygiene status $(\mathrm{p}=0.5)$ (Figure 4$)$. 
Figure 1: Bar chart shows the distribution of socioeconomic status of the patients. $X$ axis denotes the socioeconomic status and $\mathrm{Y}$ axis denotes the number of patients in each socioeconomic class. Majority of the patients $(31.6 \%)$ were from the upper middle class (green), $(31.6 \%)$ were from middle class (red) followed by $(\mathbf{1 9 . 3} \%)$ from the lower middle class (blue) and $(\mathbf{1 7 . 3 \% )}$ were from the upper class (purple).

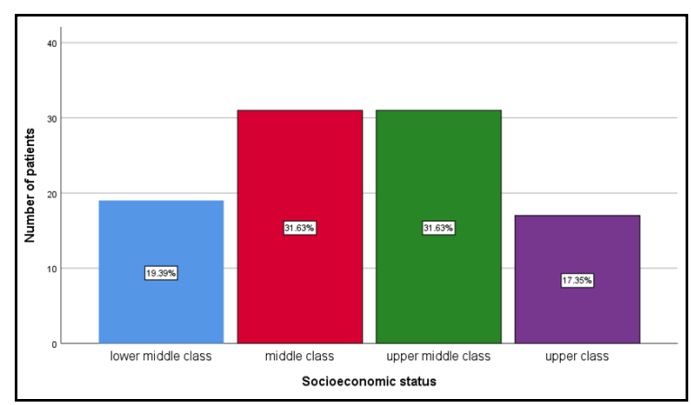

Figure 2: Bar chart with error bars show mean distribution of oral hygiene index scores among different socio-economic status groups. $\mathrm{X}$ axis denotes the socioeconomic status of the patients and $\mathrm{Y}$ axis denotes the mean oral hygiene index score. One -way ANOVA test was done and found to be not significant $(P=0.490 ; p>0.05)$. However, the mean oral hygiene score was high for the lower middle class.

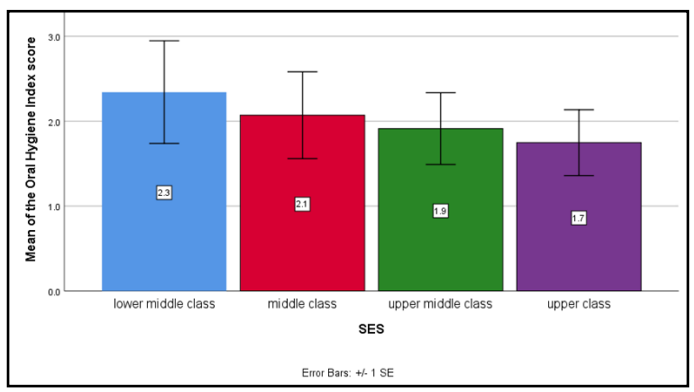

Figure 3: Bar chart with error bars show mean distribution of periodontal index scores among different socio-economic status groups. $\mathrm{X}$ axis denotes the socioeconomic status of the patients and $\mathrm{Y}$ axis denotes the mean periodontal index score.

One -way ANOVA test was done and found to be not significant ( $p$ value $=0.292, p>0.05)$. The mean of the periodontal index score was higher in the lower middle class.

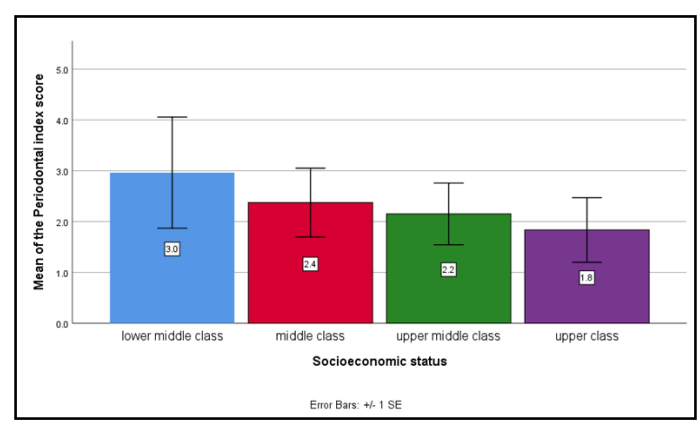

Figure 4: Bar chart shows the association between socioeconomic status and oral hygiene status of the patients. $\mathrm{X}$ axis denotes the socioeconomic status of the participants and $\mathrm{Y}$ axis represents the number of the patients. Chi-square association test was done and found to be not significant (Pearson's Chi-square value-0.266; $\mathrm{p}=0.51$. $(>0.05)$ ). However, good oral hygiene was seen to be high in the middle class patients $(12.2 \%)$.

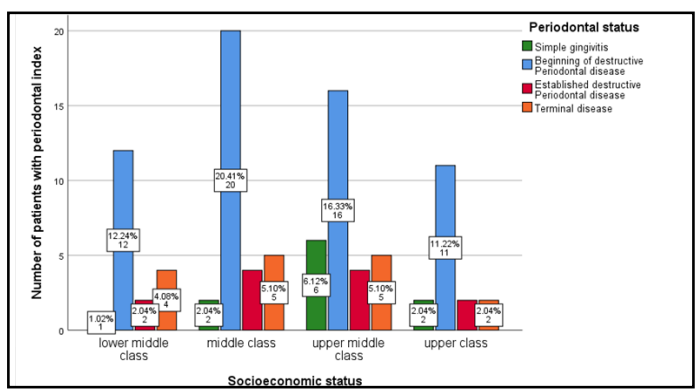

Majority of the patients were from the upper middle class $(31.6 \%)$, middle class $(31.6 \%)$ followed by lower middle class $(19.4 \%)$ and followed by upper class $(17.3 \%)$. In the lower middle class, 12 had beginning of the destructive periodontal disease, 2 had estab- lished destructive periodontal disease , 1 had simple gingivitis and 4 had terminal disease. In the middle class, 20 had beginning of the destructive periodontal disease, 4 had established destructive periodontal disease, 2 had simple gingivitis and 5 had terminal disease. In the upper class, 11 had beginning of the destructive 
Figure 5: Bar chart shows the association between socioeconomic status and periodontal status of the patients. $\mathrm{X}$ axis denotes the socioeconomic status of the participants and $\mathrm{Y}$ axis represents the number of the patients. Chi square association test was done and found to be not significant (Pearson's Chi-square value- $0.710 ; p=0.90$. $(>0.05)$ ). However, patients with simple gingivitis was seen in the upper middle class patients $(6.1 \%)$.

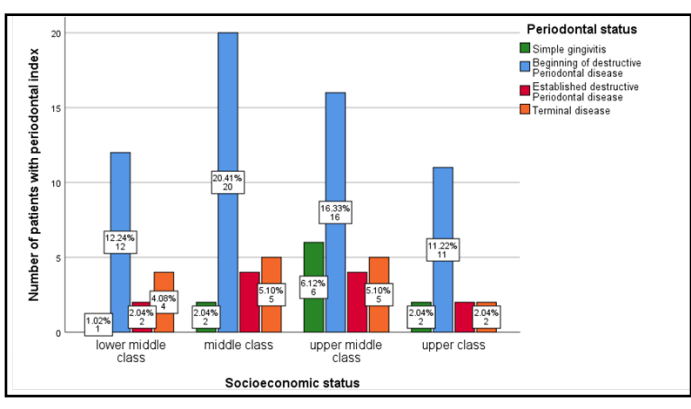

periodontal disease, 2 had established destructive periodontal disease, 2 had simple gingivitis and 2 had terminal disease. In the upper middle class, 16 had beginning of the destructive periodontal disease, 4 had established destructive periodontal disease , 6 had simple gingivitis and 5 had terminal disease. It was found that the upper middle class had better periodontal status (54.5\%) and the results were not statistically significant. Socioeconomic status and periodontal status also showed no significance $(p=0.9)$ (Figure 5)

Various studies have shown an impact of socio-economic status on the oral health of an individual. It has been also proven that there is a significant association between the individual's oral health and awareness about the same. Individuals from lower socio-economic groups unable to use the oral hygiene aids like mouthwash, interproximal brushes and various medicated toothpaste because of their higher cost. Competitively individuals from higher economic status have access to all the above mentioned aids and also the awareness of its cole [42].

In the present study, among 98 individuals with different socioeconomic status, the upper middle class people had better oral health and better periodontal health. According to Chandra Sekar et al [43] all the subjects in the upper SES were using brush and paste for cleaning. Gautham DK et al [18] have shown a positive correlation between the periodontal status of an individual and socio economic status. In our study we did not see a statistical significance association but it was found that patients with high SES had better oral and periodontal health.

The results of the study done by Bertoldi [8] and Gundala et al(44) showed that the lower SES have lost access to the utilization of the dental services and which resulted in poor oral hygiene and periodontal status compared to upper SES people. A study of Vogt et al. found $47 \%$ of prevalence of periodontal disease in low-income. [45] The study done by Opeodu et al [3] shows no significant relationships exist between the periodontal health status and SES. Study by Tesini, it was reported that SES has no significant impact on oral hygiene status of the subjects [46]. The results of these studies were similar to the results of our study that there was no statistical association between socioeconomic status with oral hygiene status and periodontal status. This could have been due to the fact that the majority of our patients attend the clinic for symptomatic treatment. According to a few studies, although parents were having good educational background and residential location was in an urban area of the state, still subjects were having poor oral hygiene status. $[47,48]$ Our institution is passionate about high quality evidence based research and has ex- celled in various fields [49-59].

The limitations of the study were that it was a retrospective study with a limited sample size. Furthermore longitudinal prospective studies with analysis of other environmental factors that contribute to the oral hygiene status and periodontal status are needed to prove the hypothesis.

\section{Conclusion}

Within the limits of the study it is found that oral hygiene status and periodontal status are not significantly associated with socioeconomic status but a better oral health and periodontal health was seen in upper class and upper middle class people. However, the economic status of the individual and unawareness about the oral health needs to be given attention since they act as barriers to utilize the dental services.

\section{Authors Contributions}

First author Keerthana R performed the analysis, and interpretation and wrote the manuscript. Second author Arthi Balasbramaniam contributed to conception, data design, analysis, interpretation and critically revised the manuscript. Third author Manjari Chaudhary participated in the study and revised the manuscript. All the three authors have discussed the results and contributed to the final manuscript.

\section{Acknowledgements}

We thank Saveetha Dental college for allowing us to access the patient's records and complete the research study.

\section{Conflict of interest}

No conflict of interest.

\section{References}

[1]. Mohapatra S, Kumar RP, Arumugham IM, Sakthi D, Jayashri P. Assessment of Microhardness of Enamel Carious Like Lesions After Treatment with Nova Min, Bio Min and Remin Pro Containing Toothpastes: An in Vitro Study. Indian J Public Health Res Dev. 2019 Oct 1;10(10):375.

[2]. Shaju JP, Zade RM, Das M. Prevalence of periodontitis in the Indian population: A literature review. J Indian Soc Periodontol. 2011 Jan;15(1):29.

[3]. Opeodu OI, Arowojolu MO. Effect of Social Class on the Prevalence and Severity of Periodontal Disease . Ann. Ib. Postgrad. Med. 2011:5. 
[4]. Prabakar J, John J, Srisakthi D. Prevalence of dental caries and treatment needs among school going children of Chandigarh. Indian J Dent Res. 2016 Sep-Oct;27(5):547-552.Pubmed PMID: 27966516.

[5]. Mathew MG, Samuel SR, Soni AJ, Roopa KB. Evaluation of adhesion of Streptococcus mutans, plaque accumulation on zirconia and stainless steel crowns, and surrounding gingival inflammation in primary molars: randomized controlled trial. Clin Oral Investig. 2020 Sep;24(9):3275-3280.Pubmed PMID: 31955271

[6]. Leelavathi L. Nicotine Replacement Therapy for Smoking Cessation-An Overview. Indian J Public Health Res Dev. 2019 Nov 1;10(11):3588.

[7]. Prabakar J, John J, Arumugham IM, Kumar RP, Sakthi DS. Comparing the Effectiveness of Probiotic, Green Tea, and Chlorhexidine- and Fluoride-containing Dentifrices on Oral Microbial Flora: A Double-blind, Randomized Clinical Trial. Contemp Clin Dent. 2018 Oct-Dec;9(4):560-569.Pubmed PMID: 31772463

[8]. Bertoldi C, Lalla M, Pradelli JM, Cortellini P, Lucchi A, Zaffe D. Risk factors and socioeconomic condition effects on periodontal and dental health: A pilot study among adults over fifty years of age. Eur J Dent. 2013 Jul;7(3):336-346.Pubmed PMID: 24926214.

[9]. Prabhakar AR, Murthy SA, Sugandhan S. Comparative evaluation of the length of resin tags, viscosity and microleakage of pit and fissure sealants an in vitro scanning electron microscope study. Contemp Clin Dent. 2011 Oct;2(4):324-30.Pubmed PMID: 22346161

[10]. Locker D, Slade G. Association between clinical and subjective indicators of oral health status in an older adult population. Gerodontology. 1994 Dec;11(2):108-14.Pubmed PMID: 7750964.

[11]. Prabakar J, John J, Arumugham IM, Kumar RP, Srisakthi D. Comparative evaluation of retention, cariostatic effect and discoloration of conventional and hydrophilic sealants-A single blinded randomized split mouth clinical trial. Contemp. Clin. Dent. 2018 Sep;9(Suppl 2):S233.

[12]. Khatri SG, Madan KA, Srinivasan SR, Acharya S. Retention of moisturetolerant fluoride-releasing sealant and amorphous calcium phosphate-containing sealant in 6-9-year-old children: A randomized controlled trial. J Indian Soc Pedod Prev Dent. 2019 Jan-Mar;37(1):92-98.Pubmed PMID: 30804314

[13]. Pratha AA, Prabakar J. Comparing the effect of Carbonated and energy drinks on salivary pH-In Vivo Randomized Controlled Trial. Res J Pharm Technol. 2019;12(10):4699-702.

[14]. Pavithra RP, Jayashri P. Influence of naturally occurring phytochemicals on oral health. Res J Pharm Technol. 2019;12(8):3979-83

[15]. Samuel SR, Acharya S, Rao JC. School Interventions-based Prevention of Early-Childhood Caries among 3-5-year-old children from very low socioeconomic status: Two-year randomized trial. J Public Health Dent. 2020 Jan;80(1):51-60.Pubmed PMID: 31710096

[16]. Kingma E, Chisnall B, McCabe MM. Interdisciplinary workshop on concepts of health and disease: report.2011;17: 1018-22.

[17]. Kumar RP, Vijayalakshmi B. Assessment of fluoride concentration in ground water in Madurai district, Tamil Nadu, India. Res J Pharm Technol. 2017;10(1):309-10.

[18]. Gautam DK, Vikas J, Amrinder T, Rambhika T, Bhanu K. Evaluating dental awareness and periodontal health status in different socioeconomic groups in the population of Sundernagar, Himachal Pradesh, India. J Int Soc Prev Community Dent. 2012 Jul;2(2):53-7.Pubmed PMID: 24478968.

[19]. Kumar RP, Vijayalakshmi B. Assessment of fluoride concentration in ground water in Madurai district, Tamil Nadu, India. Res J Pharm Technol. 2017;10(1):309-10.

[20]. Letelier A, Heilmann A, Watt RG, Jivraj S, Tsakos G. Does intergenerational social mobility affect the general health, oral health, and physical function of older adults in England?. Lancet. 2016 Nov 1;388:S68.

[21]. Kumar RP, Preethi R. Assessment of water quality and pollution of Porur, Chembarambakkam and Puzhal Lake. Res J Pharm Technol. 2017;10(7):2157-9.

[22]. Neralla M, Jayabalan J, George R, Rajan J, P SKM HA. Role of nutrition in rehabilitation of patients following surgery for oral squamous cell carcinoma. Int. J. Pharm. Sci. Res. 2019 Oct 16;10(4):3197-203.

[23]. Kadtane SS, Bhaskar DJ, Agali C, Punia H, Gupta V, Batra M, et al. Periodontal Health Status of Different Socio-economic Groups in Out-Patient Department of TMDC \& RC, Moradabad, India. J Clin Diagn Res. 2014 Jul;8(7):ZC61-4.Pubmed PMID: 25177641

[24]. Hafeez N. Accessory foramen in the middle cranial fossa. Res J Pharm Technol. 2016;9(11):1880-2.

[25]. Krishnan RP, Ramani P, Sherlin HJ, Sukumaran G, Ramasubramanian A, Jayaraj G, et al. Surgical Specimen Handover from Operation Theater to Laboratory: A Survey. Ann Maxillofac Surg. 2018 Jul-Dec;8(2):234-238. Pubmed PMID: 30693238.

[26]. Somasundaram S, Ravi K, Rajapandian K, Gurunathan D. Fluoride Content of Bottled Drinking Water in Chennai, Tamilnadu. J Clin Diagn Res.
2015 Oct;9(10):ZC32-4.Pubmed PMID: 26557612.

[27]. Felicita AS. Orthodontic extrusion of Ellis Class VIII fracture of maxillary lateral incisor - The sling shot method. Saudi Dent J. 2018 Jul;30(3):265269.Pubmed PMID: 29942113.

[28]. Kumar S, Rahman R. Knowledge, awareness, and practices regarding biomedical waste management among undergraduate dental students. Asian J Pharm Clin Res. 2017;10(8):341.

[29]. Gurunathan D, Shanmugaavel AK. Dental neglect among children in Chennai. J Indian Soc Pedod Prev Dent. 2016 Oct 1;34(4):364.

[30]. Sneha S. Knowledge and awareness regarding antibiotic prophylaxis for infective endocarditis among undergraduate dental students. Asian J Pharm Clin Res. 2016 Oct 1:154-9.

[31]. Dhinesh B, Lalvani JI, Parthasarathy M, Annamalai K. An assessment on performance, emission and combustion characteristics of single cylinder diesel engine powered by Cymbopogon flexuosus biofuel. Energy Convers Manage. 2016 Jun 1;117:466-74.

[32]. Choudhari S, Thenmozhi MS. Occurrence and Importance of Posterior Condylar Foramen. Res J Pharm Technol. 2016;9(8):11-43.

[33]. Paramasivam A, Vijayashree Priyadharsini J, Raghunandhakumar S. N6 adenosine methylation (m6A): a promising new molecular target in hypertension and cardiovascular diseases. Hypertens Res. 2020 Feb;43(2):153154.Pubmed PMID: 31578458.

[34]. Wu F, Zhu J, Li G, Wang J, Veeraraghavan VP, Krishna Mohan S, et al. Biologically synthesized green gold nanoparticles from Siberian ginseng induce growth-inhibitory effect on melanoma cells (B16). Artif Cells Nanomed Biotechnol. 2019 Dec;47(1):3297-3305.Pubmed PMID: 31379212.

[35]. Palati S, Ramani P, Shrelin HJ, Sukumaran G, Ramasubramanian A, Don $\mathrm{KR}$, et al. Knowledge, Attitude and practice survey on the perspective of oral lesions and dental health in geriatric patients residing in old age homes. Indian J Dent Res. 2020 Jan-Feb;31(1):22-25.Pubmed PMID: 32246676.

[36]. Saravanan M, Arokiyaraj S, Lakshmi T, Pugazhendhi A. Synthesis of silver nanoparticles from Phenerochaete chrysosporium (MTCC-787) and their antibacterial activity against human pathogenic bacteria. Microb Pathog. 2018 Apr;117:68-72.Pubmed PMID: 29427709.

[37]. Govindaraju L, Gurunathan D. Effectiveness of Chewable Tooth Brush in Children-A Prospective Clinical Study. J Clin Diagn Res. 2017 Mar;11(3):ZC31-ZC34.Pubmed PMID: 28511505.

[38]. Vijayakumar Jain S, Muthusekhar MR, Baig MF, Senthilnathan P, Loganathan S, Abdul Wahab PU, et al. Evaluation of Three-Dimensional Changes in Pharyngeal Airway Following Isolated Lefort One Osteotomy for the Correction of Vertical Maxillary Excess: A Prospective Study. J Maxillofac Oral Surg. 2019 Mar;18(1):139-146.Pubmed PMID: 30728705.

[39]. Shivakumar M. Oral Hygiene Index: Simplified (Greene and Vermillion-1964) [Internet]. Preventive and Community Dentistry: Clinical Record Book. 2006. p. 26-26. Available from: http://dx.doi.org/10.5005/jp/ books/10669_6

[40]. Russell AL. The Periodontal Index [Internet]. Vol. 38, Journal of Periodontology. 1967. p. 585-91. Available from: http://dx.doi.org/10.1902/ jop.1967.38.6_part2.585

[41]. Saleem SM, Community Medicine. Modified Kuppuswamy socioeconomic scale updated for the year 2019 [Internet]. Vol. 6, Indian Journal of Forensic and Community Medicine. 2019. p. 1-3. Available from: http://dx.doi. org/10.18231/2394-6776.2019.0001

[42]. Narayan DP. Assessment of Oral Health Status Using WHO Basic Oral Health Survey Form [Internet]. Clinical Manual for Public Health Dentistry and Practical Record Book. 2015. p. 260-260. Available from: http://dx.doi. org/10.5005/jp/books/12448_20

[43]. Shekar BRC, Manjunath BC, Reddy CVK, Suma S. Dental health awareness, attitude, oral health-related habits, and behaviors in relation to socioeconomic factors among the municipal employees of Mysore city [Internet]. Vol. 4, Annals of Tropical Medicine and Public Health. 2011. p. 99. Available from: http://dx.doi.org/10.4103/1755-6783.85761

[44]. Chava V, Gundala R. Effect of lifestyle, education and socioeconomic status on periodontal health [Internet]. Vol. 1, Contemporary Clinical Dentistry. 2010. p. 23. Available from: http://dx.doi.org/10.4103/0976-237x.62516

[45]. Vogt M, Sallum AW, Cecatti JG, Morais SS. Factors associated with the prevalence of periodontal disease in low-risk pregnant women [Internet]. Vol. 9, Reproductive Health. 2012. Available from: http://dx.doi. org/10.1186/1742-4755-9-3

[46]. Tesini DA. Age, degree of mental retardation, institutionalization, and socioeconomic status as determinants in the oral hygiene status of mentally retarded individuals [Internet]. Vol. 8, Community Dentistry and Oral Epidemiology. 1980. p. 355-9. Available from: http://dx.doi. org/10.1111/j.1600-0528.1980.tb01307.x

[47]. Anders PL, Davis EL. Oral health of patients with intellectual disabilities: A systematic review [Internet]. Vol. 30, Special Care in Dentistry. 2010. p. 110 7. Available from: http://dx.doi.org/10.1111/j.1754-4505.2010.00136.x 
[48]. Jongh A de, de Jongh A, van Houtem C, van der Schoof M, Resida G, Broers D. Oral health status, treatment needs, and obstacles to dental care among noninstitutionalized children with severe mental disabilities in The Netherlands [Internet]. Vol. 28, Special Care in Dentistry. 2008. p. 111-5. Available from: http://dx.doi.org/10.1111/j.1754-4505.2008.00022.x

[49]. Vijayashree Priyadharsini J. In silico validation of the non-antibiotic drugs acetaminophen and ibuprofen as antibacterial agents against red complex pathogens. J Periodontol. 2019 Dec;90(12):1441-1448.Pubmed PMID: 31257588.

[50]. Pc J, Marimuthu T, Devadoss P, Kumar SM. Prevalence and measurement of anterior loop of the mandibular canal using CBCT: A cross sectional study. Clin Implant Dent Relat Res. 2018 Apr 6;20(4):531-4.

[51]. Ramesh A, Varghese S, Jayakumar ND, Malaiappan S. Comparative estimation of sulfiredoxin levels between chronic periodontitis and healthy patients - A case-control study. J Periodontol. 2018 Oct;89(10):1241-1248.Pubmed PMID: 30044495.

[52]. Ramadurai N, Gurunathan D, Samuel AV, Subramanian E, Rodrigues SJ. Effectiveness of $2 \%$ Articaine as an anesthetic agent in children: randomized controlled trial. Clin Oral Investig. 2019 Sep;23(9):3543-50.

[53]. Sridharan G, Ramani P, Patankar S, Vijayaraghavan R. Evaluation of salivary metabolomics in oral leukoplakia and oral squamous cell carcinoma. J Oral Pathol Med. 2019 Apr;48(4):299-306.

[54]. Ezhilarasan D, Apoorva VS, Ashok Vardhan N. Syzygium cumini extract induced reactive oxygen species-mediated apoptosis in human oral squamous carcinoma cells. J Oral Pathol Med. 2019 Feb;48(2):115-121.Pubmed PMID: 30451321.

[55]. Mathew MG, Samuel SR, Soni AJ, Roopa KB. Evaluation of adhesion of Streptococcus mutans, plaque accumulation on zirconia and stainless steel crowns, and surrounding gingival inflammation in primary molars: randomized controlled trial. Clin Oral Investig. 2020 Sep;24(9):3275-3280.Pubmed PMID: 31955271.

[56]. Samuel SR. Can 5-year-olds sensibly self-report the impact of developmental enamel defects on their quality of life? Int J Paediatr Dent. 2021 Mar;31(2):285-286.Pubmed PMID: 32416620.

[57]. R H, Ramani P, Ramanathan A, R JM, S G, Ramasubramanian A, et al. CYP2 C9 polymorphism among patients with oral squamous cell carcinoma and its role in altering the metabolism of benzo[a]pyrene. Oral Surg Oral Med Oral Pathol Oral Radiol. 2020 Sep;130(3):306-312.Pubmed PMID: 32773350 .

[58]. Chandrasekar R, Chandrasekhar S, Sundari KKS, Ravi P. Development and validation of a formula for objective assessment of cervical vertebral bone age. Prog Orthod. 2020 Oct 12;21(1):38.Pubmed PMID: 33043408.

[59]. Vijayashree Priyadharsini J, Smiline Girija AS, Paramasivam A. In silico analysis of virulence genes in an emerging dental pathogen A. baumannii and related species. Arch Oral Biol. 2018 Oct;94:93-98.Pubmed PMID: 30015217. 